Stone, Peter H. (1974), Limitations of Climate Modeling. Third Conference on the Climatic Impact Assessment Program, Cambridge, Massachusetts (mimeogr.).

Telegadas, K. (1971). The seasonal stratospheric distribution and inventories of excess carbon-14 from March 1955 to July 1969. U.S. Atomic Energy Commission, Health and Safety Laboratory Report, 243, pp. 3-86.

Urbach, F. (1974). Field Measurements of Biologically Effective Ultraviolet Radiation and Its Relation to Skin Cancer in Man. Third Conference on the Climatic Impact Assessment Program, Cambridge, Massachusetts (mimeogr.).
WARNECK, P. (1972). Cosmic rays as a source of odd nitrogen in the stratosphere. Journal of Geophysical Research, pp. 6589-91.

Whitten, R. \& Turco, R. (1973). A Model for Studying the Effects of Injecting Constituents into the Stratosphere and Mesosphere. AIAA paper No. 73-539, $8 \mathrm{pp}$.

WhitTen, R. \& TuRco, R. (1974). The Effect of SST Emission on the Earth's Ozone Layer. Paper presented at the IAMAP/IAPSO First Special Assemblies, Melbourne, Australia, 24 pp. (mimeogr.).

WiLLETT, H. C. (1962). The relationship of total atmospheric ozone to the sunspot cycle. Journal of Geophysical Research, 67, pp. 661-70.

\title{
Resolutions of the Third International Congress of Parasitology
}

The Third International Congress of Parasitology, which took place on 25-31 August 1974 in Munich, West Germany, passed three resolutions of which the first two were environmentally significant as follows:

\section{Resolution 1}

While recognizing the gravity of recent fundamentally new problems of environmental contamination due to long-lasting synthetic chemicals, this Congress nevertheless deplores the fact that preoccupation with these particular issues has led to neglect of the relevant significance of biological contaminants. Including parasites of all kinds, these have been and remain a serious threat to human and environmental health.

Therefore, noting that the present trend towards fluctuating economies and population growth could heighten the risks of major outbreaks of communicable and vectorborne parasitic diseases, the Congress resolves that the strongest possible representations be made to every level of government and the responsible international agencies towards better support for all relevant parasitological investigations.

\section{Resolution 2}

Being concerned with the possible parasitological consequences of the increasing carriage of animals-including mammals, birds, reptiles, amphibians, and fishes, from one region to another, whether in connection with the pet trade, sport, animal husbandry, research, or zoos and game parks-the Congress urges strongly the need for more effective control of the concomitant dispersal of parasites capable of harming human, other animal, and plant, health.

The Congress emphasizes that these dangers are not restricted to introductions across international borders, but that, in some cases, movement within a country may be equally important.

Jean G. Baer, President

Third International Congress of Parasitology; Institut de Zoologie

Université de Neuchâtel

2000 Neuchâtel

Switzerland

\section{Environmental Hazards Posed by Exotic Fish Species Newly Established in Florida}

Individuals of an established, non-indigenous species of the family Cichlidae, tentatively identified as Tilapia mariae Boulenger, have been collected from freshwater canals near Miami in Dade County, Florida. This species has not been previously noted in studies of the State's exotic fauna, which includes Tilapia aurea (Steindachner), $T$. melanotheron (Ruppell), and T. mossambica (Peters) (Courtenay \& Robins, 1973).

Adults (15-30 cm long) were first seen in April 1974 in Snapper Creek Canal, and subsequently in Little River Canal, Tamiami Canal, and Coral Gables Waterway, all of which connect indirectly. Early in June 1974 , fry $(1 \mathrm{~cm}$ long) and attendant parents were collected and spawning pairs were observed. Spawning occurs on shallow-water $(0.5 \mathrm{~m})$ ledges near the canal bank where a level, circular area of gravel is fanned clear of Algae and debris. Both parents were seen near the nest or near young defending themselves against other fish-particularly the abundant exotic Cichlasoma bimaculatum (Linnaeus).

The mode of introduction of this additional Tilapia is unknown. It is thought that escapes of fish from aquariumindustry farm ponds and/or releases from private stocks are responsible, as they probably are for the introduction of the 16 other known exotics that are established in Florida (Courtenay \& Robins, 1973).

These introduced species, collectively or even individually, may possess the potential for considerable repercussions on the aquatic resources of Florida. However, knowledge of the ecologies and life-histories of the exotics is insufficient, at present, to allow prediction of the nature and extent of these effects (Lachner et al., 1970).

\section{References}

Courtenay, W. R., Jr \& Robins, C. R. (1973). Exotic aquatic organisms in Florida with emphasis on fishes: a review and recommendations. Trans. Amer. Fish. Soc., 102(1), pp. 1-12.

LAChner, E. A., Robins, C. R. \& Courtenay, W. R., Jr (1970). Exotic fishes and other aquatic organisms introduced into North America. Smithsonian Contrib. Zool., 59, pp. 1-29.

\author{
Randall G. HoGg \\ Department of Biology \\ University of Miami \\ Coral Gables \\ Florida 33124, U.S.A.
}

